\title{
Bruk av legemidler under utprøvning
}

\author{
Når nye legemidler, som ikke er ferdig utprøvd eller ennå ikke godkjent, brukes terapeutisk, kalles det \\ compassionate use på engelsk. Vi mener at bruk av legemidler under utprøvning er en god norsk betegnelse.
}

Behandling med legemidler som ennå ikke er godkjent, er et tema med begrenset omfang, men med stor aktualitet $(1,2)$. Slik bruk av legemidler kalles på engelsk compassionate use eller expanded access. Det kan omfatte ulike tidspunkter i legemiddelutprøvningen, men ofte vil det dreie seg om perioden fra søknad om godkjenning sendes inn og til det eventuelt blir godkjent. Da foreligger forskningsresultatene. Både firma og pasienter vil da kunne ønske at det tas i bruk - spesielt hvis det ser ut til å være et bedre alternativ enn eksisterende behandling.

Compassionate use brukes mest i dagligtale og om enkeltpasienter, mens expanded access er det offisielle begrepet (3). Compassionate use gir ca. 40 norske treff i Retriever, en søketjeneste for aviser, tidsskrifter og andre publikasjoner (20.11. 2015).

\section{Barmhjertighet}

«Compassionate» betyr «medfølende, medlidende, barmhjertig» (4). Bakgrunnen for å bruke dette ordet er vel at pasienter ber om barmhjertighet slik at de kan prøve medikamenter som ikke er ferdig utprøvd (5). En direkte oversettelse av compassionate i denne sammenhengen passer ikke så godt.

På nettsiden til U.S. Food and Drug Administration står det følgende forklaring på expanded access/compassionate use: «(...) is the use outside of a clinical trial of an investigational medical product (i.e., one that has not been approved by FDA)» (6). Pasienter får altså tilgang til medikamenter som ikke er godkjent, men hvor det foreligger forskningsresultater som taler for at de har effekt. I USA finnes det såkalte «rett til å prøve»-lover («right-to-try laws»), og pasienthistorier vekker gjerne stor oppmerksomhet (7).

Dette er aktuelt også i Norge. Statens legemiddelverk har et såkalt «compassionate use program», som er en ordning som produsenter kan benytte for å gjøre legemidler uten markedsføringstillatelse tilgjengelig for en gruppe pasienter (8). Dette må skilles fra ordinært godkjenningsfritak, som normalt gjelder internasjonalt godkjente medikamenter, men hvor firmaet av ulike grunner ikke har søkt om godkjenning i Norge (9).

Ettersom disse midlene kan være på ulike stadier av utprøvningen, vil vi foreslå oversettelsen legemidler under utprøvning med compassionate use i parentes forste gang det brukes i teksten.

\section{Erlend Hem \\ erlend.hem@medisin.uio.no \\ Steinar Madsen}

Erlend Hem (f. 1970) er dr.med., fagsjef ved Klinikk psykisk helse og avhengighet, Oslo universitetssykehus, og redaktør for Tidsskriftets språkspalte.

Steinar Madsen (f. 1956) er medisinsk fagdirektør i Statens legemiddelverk.
Litteratur

1. Principled compassion. Nat Med 2014; 20: 1355

2. Magnus D. Compassion and research in compassionate use. Am J Bioeth 2014; 14: 1-2

3. Brower V. Food and Drug Administration responds to pressure for expanded drug access. J Natl Cancer Inst 2014: 106: dju171.

4. Compassionate. I: Stor engelsk-norsk ordbok. www.ordnett.no/search?search=compassionate\& lang=en (20.11.2015)

5. Rosenblatt M, Kuhlik B. Principles and challenges in access to experimental medicines. JAMA 2015: 313: 2023-4

6. Expanded Access (Compassionate Use). US Food and Drug Administration 19.11.2015. www.fda.gov/ NewsEvents/PublicHealthFocus/

ExpandedAccessCompassionateUse/default.htm (20.11.2015)

7. Jacob JA. Questions of safety and fairness raised as Right-to-Try Movement gains steam. JAMA 2015: 314: 758-60.

8. Compassionate use program. Statens legemiddelverk 2.2. 2015. www.legemiddelverket.no/ Godkjenning_og_regelverk/Klinisk-utproving/ Compassionte-use/Sider/default.aspx (20.11.2015).

9. Godkjent eller ikke godkjent - hvilke statuser kan et legemiddel ha? Statens legemiddelverk. www.legemiddelverket.no/Godkjenning_og_ regelverk/godkjenning_av_legemidler/ Slik_godkjennes legemidler/Sider/Godkjenteller-ikke-godkjent.aspx (20.11.2015). 